\title{
Exploring consumers' knowledge and perceptions of unconventional food plants: case study of addition of Pereskia aculeata Miller to ice cream
}

\author{
Suelen MAZON ${ }^{1}$, Daiana MENIN², Bruna Marina CELLA², Carla Cristina LISE², Thiago de Oliveira VARGAS ${ }^{1}$, \\ Marina Leite Mitterer DALTOÉ2*
}

\begin{abstract}
Unconventional food plants (UFPs) are by definition little known and infrequently consumed by population, although are recognized as having high nutritional value and economic potential. The objective was to assess the knowledge about UFPs by the population in the southwestern region of the state of Paraná, Brazil; and more particularly to evaluate the holistic perception of an ice cream prepared with the UFP ora-pro-nóbis, a plant that is gaining attention in recent years We applied a questionnaire to assess knowledge of several UFPs; check-all-that-apply questions to evaluate the knowledge, habits and perceptions regarding UFPs; and word association (WA) and acceptance tests for holistic and hedonic evaluation of the ice cream. The results revealed that the best known UFP species were taro and roselle, followed by ora-pro-nóbis and lamb's ear. They also revealed that among participants, the majority (63\%) had heard of UFPs, but only $19.4 \%$ stated they had the custom of eating these plants. The respondents also indicated interest in buying UFPs, but stated it was not easy to find them for sale. In the WA test, ice cream was described mainly in the categories tasty, innovation, sweet taste, plant flavor, smooth and creamy, and the acceptance index was $74 \%$.
\end{abstract}

Keywords: check-all-that-apply; correspondence analysis; ora-pro-nóbis; word association.

Practical Application: Strategic moves to increase UFP consumption can be guided by increased public knowledge of and acceptance of UFP.

\section{Introduction}

Many unconventional food plants (UFPs) are recognized by the scientific community as important complementary sources to combat nutritional deficiencies (Bacchetta et al., 2016; Barreira et al., 2015; Menendez-Baceta et al., 2017; Sanchez-Bel et al., 2015). They often contain high concentrations of minerals and proteins and high levels of vitamins $\mathrm{A}$ and $\mathrm{C}$, along with significant percentages of fiber (Aberoumand \& Deokule, 2009). However, due to the lack of knowledge of these plants, their consumption around the world is low (Almeida \& Corrêa, 2012; Bacchetta et al., 2016; Menendez-Baceta et al., 2017).

A recent study highlights the importance of involving different sectors to obtain holistic data for consequent promotion of the use of UFPs, such as pharmeceutical, botanical, agronomic, nutritional, immunological, rural and gastronomic (Bacchetta et al., 2016).

The most common UFPs found in the southwestern region of Paraná, Brazil, are verdolaga (Portulaca oleraceae), nasturtium (Tropaeolum majus), air yam (Dioscorea bulbifera), amaranth (Amaranthus spp.), lamb's ear (Stachys byzantina), taro (Colocasia esculenta), roselle (Hibiscus sabdariffa) and ora-pro-nóbis (Pereskia aculeata), and they are most often classified as weeds (amaranth and verdolaga) or medicinal plants (lamb's ear and roselle).

Verdolaga contains high concentrations of omega-3, omega- 6 and antioxidant compounds (Oliveira et al., 2009). It is used in folk medicine for its diuretic, anti-inflammatory and vermifuge effects (Albuquerque et al., 2007; Xiang et al., 2005). As a food, it can be consumed in salads, juices and stir-fries, imparting a mildly acidic flavor (Oliveira et al., 2009).

Nasturtium is an ornamental, edible and medicinal plant. In cuisine, the flowers are used to decorate plates, especially salads, and have a spicy flavor (Mlcek \& Rop, 2011). For medicinal use, it is considered an important source of carotenoids (Garzón \& Wrolstad, 2009), and for having antibacterial, diuretic, expectorant and laxative activities (Mlcek \& Rop, 2011).

Air yam, as the name suggests, is a bulb that grows above ground. It is used in folk medicine to treat cancer and skin infections (Wang et al., 2012). In cuisine, it is used in baked goods and purees, to replace potato flour.

Amaranth is a plant with many uses, of all parts. It is rich in iron, potassium, calcium, magnesium and vitamins (Jiménez-Aguilar \& Grusak, 2017). It also has nutraceutical properties for the treatment of infections, hepatic problems, cancer and degenerative diseases (Peter \& Gandhi, 2017).

Taro is rich in fibers ( 0.6 to $0.8 \mathrm{~g} / 100 \mathrm{~g}$ ), proteins ( 2 to $6 \mathrm{~g} / 100 \mathrm{~g}$ ), carbohydrates (70-80 g/100 g) and vitamins (Kumar et al., 2017). As an important source of starch, it is employed to make four 
and is consumed in soups and purees. Regarding medicinal use, it is recognized as having wound-healing properties (Gonçalves et al., 2013).

Roselle is also known for its nutraceutical properties, since its flowers and fruits are rich in phenolic compounds, mainly anthocyanins, which have potent antioxidant, anti-inflammatory, anti-obesity, diuretic and anti-cancer activities, besides combating degenerative diseases (Riaz \& Chopra, 2018). In cuisine, its flowers are used to prepare teas, jellies, and juices. Extracts from the flowers are also used as natural colorants in the food, cosmetic and pharmeceutical industries (Jabeur et al., 2017).

Lamb's ear is used in folk medicine to combat respiratory diseases. Some studies have also reported it alleviates abdominal pain and menstrual disturbances (Sarikurkcu et al., 2016). In cuisine, its leaves are prepared breaded and fried as an appetizer.

Among these UFP species, ora-pro-nóbis (OPN) stands out (Kinupp \& Lorenzi, 2014). It is often referred to as "green meat" or "vegetable meat" due to its high protein content (Madeira et al., 2016). Research also indicates its leaves are an important source of fiber, calcium and iron (Almeida et al., 2012; Martin et al., 2017), bioactive compounds such as antioxidants (Almeida et al., 2012) and anti-inflammatory substances (Pinto et al., 2015). Encouragement of its use is seen as an important strategy to improve nutrition and income among poor people (Almeida \& Corrêa, 2012). It can be consumed raw, cooked or as an ingredient in food products (Amaral et al., 2018). In particular, the absence of toxicity of its leaves and high mucilage concentration (Martin et al., 2017) make it attractive for use in processed foods.

The objective of this study was to assess public knowledge, habits and perception regarding UFPs, and in particular, the holistic and hedonic perception of an ice cream prepared with ora-pro-nóbis (OPN).

\section{Materials and methods}

\subsection{Participants}

The survey was conducted among 84 participants ( 31 men and 53 women), with ages between 20 and 51 years, in the city of Pato Branco, located in the state of Paraná, Brazil.

\subsection{Questionnaire to evaluate recognition of UFPs}

To learn which UFPs are known to the population, we applied a questionnaire containing the images and names of eight UFPs commonly found in the region studied. The participants were asked to mark an $\mathrm{X}$ under the unconventional food plants they recognized. The answers were submitted to the z-test, a significance test that allows accepting or rejecting hypotheses. In this study, the test involved all the images at significance level of 5\% (Belusso et al., 2016).

\subsection{Check-All-That-Apply (CATA) questionnaire to assess the knowledge, habits and perceptions regarding the UFPs.}

To evaluate the knowledge, habits and perceptions regarding the UFPs, we applied a CATA questionnaire composed of 16 statements. For each statement there was an opposite one, with the intention of obtaining reliable results. The responses of participants who marked a statement as well as its opposite were eliminated.

The statements were presented in four randomly selected orders (four versions of the questionnaire), to prevent errors in function of the order (Ares \& Jaeger, 2013). Again, the z-test was applied to the data at significance of 5\% (Belusso et al., 2016).

\subsection{Preparation of the ice cream containing ora-pro-nóbis}

Since ora-pro-nóbis is rich in mucilage (Martin et al., 2017), it was used in the formulation with the main function of replacing the emulsifiers and stabilizers normally used in ice cream. The ice cream was prepared with the following ingredients: $28 \%$ milk, $28 \%$ cream, $13.5 \%$ egg yolk, $8 \%$ sugar and $22.5 \%$ raw ora-pro-nóbis leaves.

The ingredients were combined as described by Rodrigues et al. (2006). The milk and cream were mixed under constant stirring at $50{ }^{\circ} \mathrm{C}$. At the same time, the egg yolks and part of the sugar (50\%) were whipped until obtaining a smooth cream, and the ora-pro-nóbis leaves and the rest of the sugar were boiled in water for 15 minutes to make a syrup. Then this syrup was mixed with the milk and cream to obtain a second syrup, which was pasteurized at $70^{\circ} \mathrm{C}$ for 30 minutes under constant stirring. After pasteurization, the syrup was cooled in an ice bath to $-4^{\circ} \mathrm{C}$ and packaged and stored for maturation at $4{ }^{\circ} \mathrm{C}$ for 4 hours. After maturation, the syrup was whipped in an ice bath at $-8^{\circ} \mathrm{C}$ for 10 minutes, after which it was placed in a freezer $\left(-17^{\circ} \mathrm{C}\right)$ and stored until the taste tests.

\subsection{Word Association (WA) tests and acceptance trials of the ora-pro-nóbis ice cream}

To the taste trials of the ora-pro-nóbis ice cream, the samples were removed from the freezer $\left(-17^{\circ} \mathrm{C}\right) 5$ minutes beforehand (Varela et al., 2014). Each sample was labeled with a random three-digit code and served in small plastic cups (50 mL).

For the WA test, the participants were told: "Please write the first four words representing sensations or feelings that come to your mind when tasting the sample of ora-pro-nóbis ice cream."

The WA analysis was based on Antmann et al. (2011). All the associations were included and the words with similar meanings were grouped. Four researchers conducted the grouping procedure independently. After evaluating the data individually, they met to reach agreement about the classifications. The final categories and their names were determined by consensus among the researchers, considering the four independent classifications. Categories consisting of words mentioned by more than $5 \%$ of the participants were included in the analysis.

The ora-pro-nóbis ice cream was submitted to subjective evaluation on a 9-point hedonic scale (ISO 11136, International Organization for Standardization, 2017).

Correspondence analysis was applied to verify the association between the hedonic responses and the words suggested in the word association test (Mitterer-Daltoé et al., 2017). For statistical analysis, the nine points were reduced to three 
groups: Group 1 (points 1, 2 and 3); Group 2 (points 4, 5 and 6); and Group 3 (points 7, 8 and 9). The data were analyzed by the Statistica 12.7 program.

The study was approved by the Ethics Committee for Human Research of Federal Technological University of Paraná (number 93290318.0.00005547).

\section{Results and discussion}

\subsection{Recognition of the UFPs}

Figure 1 presents the results of the knowledge about the UFPs. Taro and roselle were the best known plants, marked by $76.2 \%$ and $73.4 \%$ of the respondents, respectively.

The next best-known UFPs were ora-pro-nóbis, marked by $44.1 \%$ of the participants; lamb's ear, $40.5 \%$; and air yam, $36.9 \%$. Nasturtium and amaranth were recognized by $28.6 \%$ and $27.4 \%$ of the participants, and verdolaga was in last place, with only $11.9 \%$.

\subsection{Check-All-That-Apply (CATA) questionnaire}

The CATA questionnaire contained statements about the knowledge, habits and perceptions regarding the UFPs. Table 1 shows the frequency of each statement marked. The z-test indicates the significance of the difference between each statement and its opposite.
Table 1. Results of the check-all-that-apply questionnaire. Frequencies for each statement and z-test.

\begin{tabular}{|c|c|c|}
\hline Statements & Checks & Z-test \\
\hline P1. I've never heard about UFPs. & 14 & 6.26 \\
\hline P2. I've heard about UFPs. & 53 & \\
\hline P3. I customarily consume UFPs. & 16 & 4.97 \\
\hline P4. I don't consume UFPs. & 47 & \\
\hline P5. I'd buy UFPs at markets regardless of the price. & 9 & 6.22 \\
\hline $\begin{array}{l}\text { P6. If the price were accessible, I'd buy UFPs at } \\
\text { markets. }\end{array}$ & 47 & \\
\hline P7. I grow at least one UFP at home. & 13 & 7.60 \\
\hline P8. I don't grow UFPs at home. & 62 & \\
\hline P9. I've already worked with/studied UFPs. & 16 & 4.82 \\
\hline P10. I've never worked with/studied UFPs. & 46 & \\
\hline $\begin{array}{l}\text { P11. I don't often find UFPs at supermarkets and } \\
\text { street markets. }\end{array}$ & 45 & 7.65 \\
\hline $\begin{array}{l}\text { P12. I often find UFPs at supermarkets and street } \\
\text { markets. }\end{array}$ & 1 & \\
\hline $\begin{array}{l}\text { P13. Even if I had the opportunity, I wouldn't } \\
\text { consume UFPs, even knowing of their health } \\
\text { benefits. }\end{array}$ & 0 & 9.73 \\
\hline $\begin{array}{l}\text { P14. If I had the opportunity, I'd consume UFPs } \\
\text { because of their health benefits. }\end{array}$ & 60 & \\
\hline $\begin{array}{l}\text { P15. I think it's risky to consume food plants not } \\
\text { normally consumed by people. }\end{array}$ & 3 & 8.30 \\
\hline $\begin{array}{l}\text { P16. I don't think it's risky to consume food plants } \\
\text { not normally consumed by people. }\end{array}$ & 56 & \\
\hline
\end{tabular}

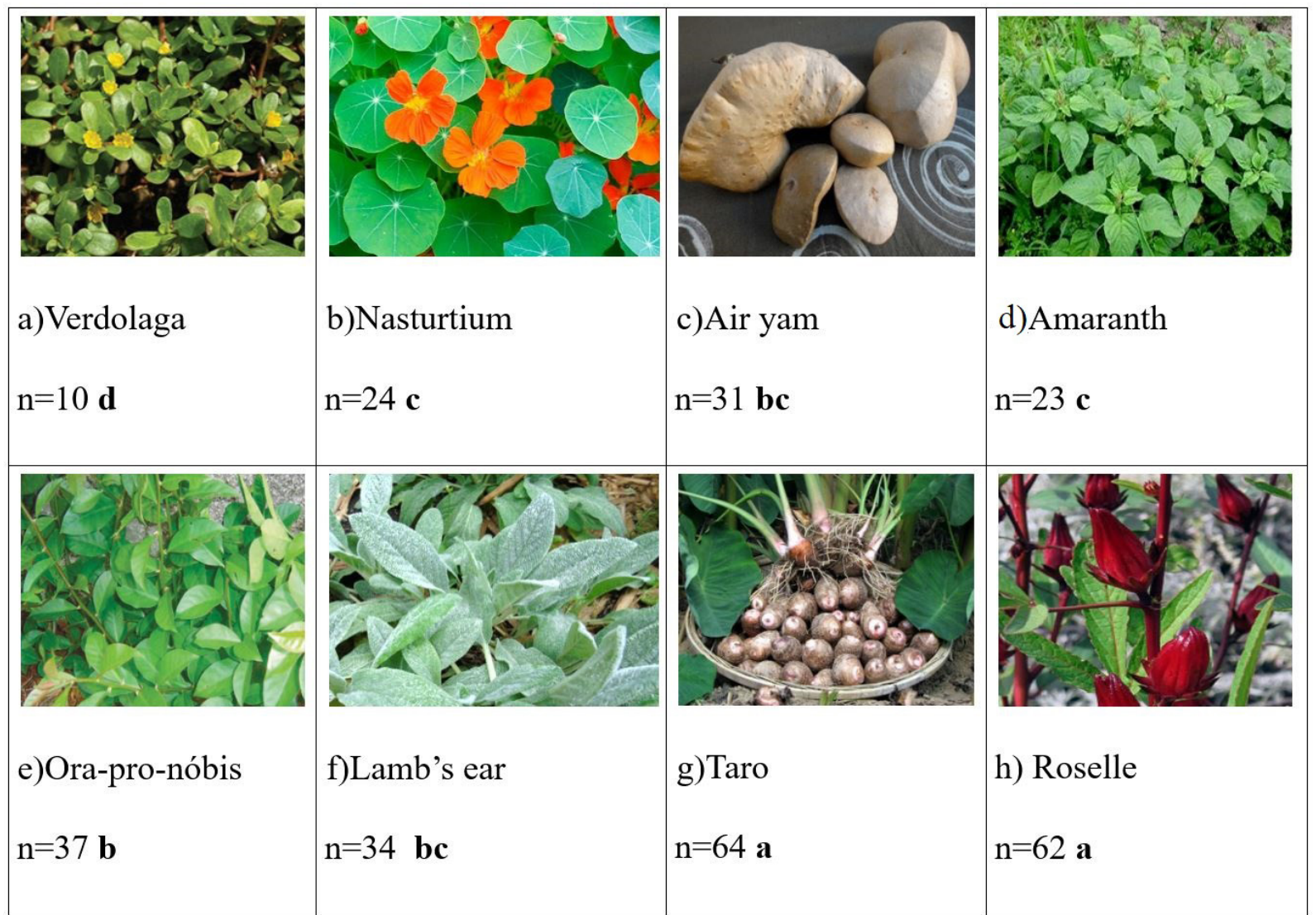

Figure 1. Number of participants who recognized each UFP. Different letters represent significant differences. $Z_{\text {critical }}=1.96$. 
The majority (63\%) of the respondents had heard of the UFPs, but only $19.4 \%$ stated they had the custom of consuming these plants. The participants also expressed interest in buying the UFPs, if the price was accessible, bud did not consider it easy to find them in commerce (supermarkets and street markets). This low consumption of UFPs but positive attitude about consuming them indicates potential for marketing efforts to increase their consumption.

Furthermore, the majority (71.4\%) of the participants expressed willingness to consume UFPs because of the beneficial health effects, and stated they did not believe it is risky to consume unconventional food plants (66.7\%). The perception of health benefits revealed by the participants also favors their promotion, since the healthy perception of a determined food has a positive influence on buying behavior (Carrillo et al., 2011; Clarke \& Best, 2017).

\subsection{Word association and hedonic test}

Table 2 presents the categories obtained by applying the word association technique. The participants spontaneously mentioned 266 terms in response to the stimulus employed. Fifteen categories were established by consensus among the four researchers who took part in analyzing the data. Words with similar meanings were grouped in the same category (Varela \& Fiszman, 2013). The categories were: milk flavor, plant flavor, egg flavor, sweet taste, bitter taste, creamy, crunchy, agreeable texture, tasty, bad, strange, smooth, refreshing, healthy and nostalgia.

As can be seen in the table, the category cited the most regarding the OPN ice cream was tasty. This category appeared 64 times, cited by $76.2 \%$ of the participants, and was represented by the words tasty, delicious, good and savory. With an acceptance index of $74 \%$, the OPN ice cream was described by the following taste/flavor sensory categories: milk flavor (10), egg flavor (5), plant flavor (17), sweet taste (23), bitter taste (5), refreshing (12) and smooth (15). With respect to texture, the responses were:

Table 2. Frequency of the categories mentioned for the ice cream containing ora-pro-nóbis.

\begin{tabular}{lc}
\hline \multicolumn{1}{c}{ Categories } & $\begin{array}{c}\text { No. of } \\
\text { mentions }\end{array}$ \\
\hline Milk flavor (milk, cream) & 10 \\
Egg flavor & 5 \\
Plant flavor (tea, salad, herbal taste, spicy) & 17 \\
Bitter taste & 5 \\
Sweet taste & 23 \\
Refreshing (fresh, chilled) & 12 \\
Smooth (neutral taste, smooth taste) & 15 \\
Creamy & 18 \\
Crunchy (crunchy, pistachio, chips, flakes) & 15 \\
Agreeable texture & 9 \\
Tasty (tasty, delicious, good, savory) & 64 \\
Bad (bad, poor texture, ugly color) & 11 \\
Innovation (exotic, innovation, different) & 43 \\
Healthy & 5 \\
Nostalgia (nostalgia, comfort, happiness, relief, interior & 14 \\
recollection, nature, peace) & \\
\hline
\end{tabular}

creamy (18), crunchy (15) and agreeable texture (9). The categories creamy and agreeable texture suggest the efficacy of using the ora-pro-nóbis as an emulsifier and stabilizer of ice cream. In turn, the term crunchy, although uncommon in characterizing ice cream, was mentioned spontaneously by $17.8 \%$ of the participants. This category, represented by the terms crunchy, pistachio, chips and flakes, refers to the sensation perceived due to the presence of small leaf segments of OPN in the ice cream.

The second most cited category was innovation. The category appeared 43 times and was represented by the words different, exotic and innovation, suggesting a perception of the product as innovative for ice cream.

The category nostalgia was mentioned 14 times (16.6\%) and was represented by the words nostalgia, comfort, happiness, relief, interior recollection, nature and peace. These reveal the influence of past experiences in the cognitive evaluation of the ice cream.

The results of the word association test indicate the potential of using ora-pro-nóbis in ice cream. This affirmation is corroborated by the positive analysis of the following categories: tasty, creamy, innovation, nostalgia and healthy (although cited by only 5 participants). The positive hedonic perception of a product/food is considered a prerequisite for success in the market (Andrade et al., 2018; Mustonen et al., 2007), and the idea of innovation in consumers' minds can be favorable, since there is growing demand for different types of food products than those traditionally available (Fernández-Ruiz et al., 2013). Paradoxically, it is known that memory has a significant effect on the positive perception of foods (Morin-Audebrand et al., 2012), and past experiences (Ajzen, 1991; Verbeke \& Vackier, 2005) and familiarity can influence the food buying behavior (Carrillo et al., 2011; Fotopoulos et al., 2009; Steptoe et al., 1995).

The responses in the healthy category corroborate the potential for application and consumption of ora-pro-nóbis, since consumers' interest in healthy foods influences their choices (Steptoe et al., 1995). Knowing the main factors underpinning food choice provides important insight about the interest and attitudes of consumers in relation to healthy foods, as well as their concerns about factors that involve the buying decision (Carrillo et al., 2011).

To combine the terms elicited by the word association technique and the hedonic evaluation and better understand the perception of consumers, we applied correspondence analysis (CA) (Beh et al., 2011; Latorres et al., 2016). CA is a technique of interdependence whose main benefit is the ability to represent rows and columns on a perceptual map (Hair et al., 2009).

Figure 2 presents the results of the CA and reveals that the first two dimensions explained $100 \%$ of the association between the categories and hedonic scale groups. The good relation between the categories and hedonic scores is corroborated by the Quality indicator, which had value of 1 for all the hedonic groups. The Quality indicator denotes the sum of the relative contributions, and is part of the variability of each profile explained by the two axes: the nearer it is to 1 , the better the representation is of a profile (González et al., 2011).

Analysis of the perceptual map reveals the associations attributed to the ora-pro-nóbis ice cream for each hedonic group. 


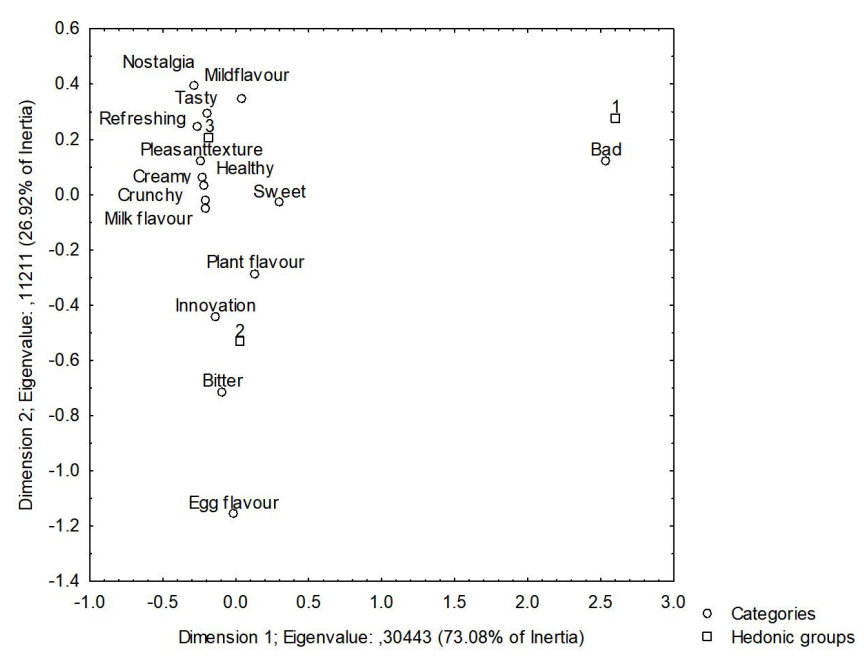

Figure 2. Correspondence analysis of the categories mentioned in the WA and points on the hadonic scale. Group 1 (points 1, 2 and 3); Group 2 (points 4, 5 and 6) and Group 3 (points 7, 8 and 9).

For Group 1, corresponding to the points "disliked extremely", "disliked very much" and "disliked moderately", the related category is bad, represented by the terms bad, bad texture and ugly color. In turn, for Group 2, represented by the points in the center of the scale, which can be called indifferent points, the associated categories are plant flavor, innovation, bitter taste and egg flavor. For Group 3, represented by positive hedonic evaluation of the ice cream, the associated categories are tasty, nostalgia, mild flavor, refreshing, pleasant texture, healthy, creamy, crunchy, sweet, and milk flavor.

It is interesting to note the new understanding generated by applying correspondence analysis to the results in relation to the descriptor innovation. When evaluated just by the number of citations $(n=43)$ (Table 2), the interpretation was that the ora-pro-nóbis ice cream, with good overall acceptance rate of $74.5 \%$, was characterized as an innovative product. However, when relating the scores and descriptors generated by the participants, it can be seen that the term innovation was associated not with the responses having the highest score, but rather by those in the indifferent part of the hedonic scale. This result indicates behavior known as food neophobia, which can be defined as fear of eating new foods (Dovey et al., 2008; Lafraire et al., 2016), and its presence has been related to lower acceptance rates (Tuorila et al., 2008).

\section{Conclusions}

Despite the low consumption of unconventional food plants by the population studied, the survey results show there is good potential for increased consumption of these plants, since the participants indicated interest in consuming them. A clear strategy to promote consumption is to increase the commercial presence, since the respondents revealed difficulty in finding the UFPs at markets. In this respect, the promotion of consumption combined with greater presence in commerce can strengthen the productive chain of UFPs, increase the income of smallholders, and add foods rich in nutrients to people's diets.
In addition to the potential market, the ice cream with OPN proved to be an important alternative use of this plant, readily acceptable by the public. This alternative use of OPN demonstrated possible uses of others UFPs could be well received which would certainly help in market development of these plants.Another important conclusions is that the correspondence analysis between the descriptors obtained by the word association method and the points on the hedonic scale revealed the possible presence of food neophobia among the participants, as indicated by the innovation descriptor. Studies in many countries have shown that food neophobia affects both the quality and variety of foods in diets. This should be considered an important factor in studies of the types of foods consumed by a population.

\section{Acknowledgements}

The authors are grateful to the Brazilian Ministry of Education's Capes Foundation for financial support.

\section{References}

Aberoumand, A., \& Deokule, S. S. (2009). Determination of elements profile of some wild edible plants. Food Analytical Methods, 2(2), 116-119. http://dx.doi.org/10.1007/s12161-008-9038-z.

Ajzen, I. (1991). The theory of planned behavior. Organizational Behavior and Human Decision Processes, 50(2), 179-211. http:// dx.doi.org/10.1016/0749-5978(91)90020-T.

Albuquerque, U. P., Medeiros, P. M., Almeida, A. L., Monteiro, J. M., Lins, E. M. F. No., Melo, J. G., \& Santos, J. P. (2007). Medicinal plants of the caatinga (semi-arid) vegetation of NE Brazil: a quantitative approach. Journal of Ethnopharmacology, 114(3), 325-354. http:// dx.doi.org/10.1016/j.jep.2007.08.017. PMid:17900836.

Almeida, M. E. F., \& Corrêa, A. D. (2012). Utilização de cactáceas do gênero Pereskia na alimentação humana em um município de Minas Gerais. Ciência Rural, 42(4), 751-756. http://dx.doi.org/10.1590/ S0103-84782012000400029.

Almeida, M. E. F., Junqueira, A. M. B., Simão, A. A., \& Corrêa, A. D. (2012). Caracterização química das hortaliças não-convencionais conhecidas como ora-pro-nobis. Bioscience Journal, 30(1), 431-439.

Amaral, T. N., Junqueira, L. A., Prado, M. E. T., Cirillo, M. A., Abreu, L. R., Costa, F. F., \& Resende, J. V. (2018). Blends of Pereskia aculeata Miller mucilage, guar gum, and gum Arabic added to fermented milk beverages. Food Hydrocolloids, 79, 331-342. http://dx.doi. org/10.1016/j.foodhyd.2018.01.009.

Andrade, J. C., Nalério, E. S., Giongo, C., Barcellos, M. D., Ares, G., \& Deliza, R. (2018). Consumer sensory and hedonic perception of sheep meat coppa under blind and informed conditions. Meat Science, 137, 201-210. http://dx.doi.org/10.1016/j.meatsci.2017.11.026. PMid:29197768.

Antmann, G., Ares, G., Salvador, A., Varela, P., \& Fiszman, S. (2011). Exploring and explaining creaminess perception: consumers' underlying concepts. Journal of Sensory Studies, 26(1), 40-47. http:// dx.doi.org/10.1111/j.1745-459X.2010.00319.x.

Ares, G., \& Jaeger, S. R. (2013). Check-all-that-apply questions: influence of attribute order on sensory product characterization. Food Quality and Preference, 28(1), 141-153. http://dx.doi.org/10.1016/j. foodqual.2012.08.016.

Bacchetta, L., Visioli, F., Cappelli, G., Caruso, E., Martin, G., Nemeth, E., Bacchetta, G., Bedini, G., Wezel, A., van Asseldonk, T., Van Raamsdonk, L., \& Mariani, F. (2016). A manifesto for the valorization 
of wild edible plants. Journal of Ethnopharmacology, 191, 180-187. http://dx.doi.org/10.1016/j.jep.2016.05.061. PMid:27321281.

Barreira, T. F., Paula, G. X. Fo., Rodrigues, V. C. C., Andrade, F. M. C., Santos, R. H. S., Priore, S. E., \& Pinheiro-Sant'ana, H. M. (2015). Diversidade e equitabilidade de Plantas Alimentícias Não Convencionais na zona rural de Viçosa, Minas Gerais, Brasil. Revista Brasileira de Plantas Medicinais, 17(4), 964-974. http://dx.doi. org/10.1590/1983-084X/14_100.

Beh, E. J., Lombardo, R., \& Simonetti, B. (2011). Short Communication A European perception of food using two methods of correspondence analysis. Food Quality and Preference, 22(2), 226-231. http://dx.doi. org/10.1016/j.foodqual.2010.10.001.

Belusso, A. C., Nogueira, B. A., Breda, L. S., \& Mitterer-Daltoé, M. L. (2016). Check all that apply (CATA) as an instrument for the development of fish products. Food Science and Technology, 36(2), 1-7. http://dx.doi.org/10.1590/1678-457X.0026.

Carrillo, E., Varela, P., Salvador, A., \& Fiszman, S. (2011). Main factors underlying consumers' food choice: a first step for the understanding of attitudes toward "healthy eating". Journal of Sensory Studies, 26(2), 85-95. http://dx.doi.org/10.1111/j.1745-459X.2010.00325.x.

Clarke, C., \& Best, T. (2017). Low-carbohydrate, high-fat dieters: characteristic food choice motivations, health perceptions and behaviours. Food Quality and Preference, 62, 162-171. http://dx.doi. org/10.1016/j.foodqual.2017.07.006.

Dovey, T. M., Staples, P. A., Gibson, E., \& Halford, J. C. (2008). Food neophobia and "picky/fussy" eating in children: a review. Appetite, 50(2-3), 181-193. http://dx.doi.org/10.1016/j.appet.2007.09.009. PMid:17997196.

Fernández-Ruiz, V., Claret, A., \& Chaya, C. (2013). Testing a spanishversion of the Food Neophobia Scale. Food Quality and Preference, 28(1), 222-225. http://dx.doi.org/10.1016/j.foodqual.2012.09.007.

Fotopoulos, C., Krystallis, A., Vassallo, M., \& Pagiaslis, A. (2009). Food Choice Questionnaire (FCQ) revisited: suggestions for the development of an enhanced general food motivation model. Appetite, 52(1), 199208. http://dx.doi.org/10.1016/j.appet.2008.09.014. PMid:18929606.

Garzón, G. A., \& Wrolstad, R. E. (2009). Major anthocyanins and antioxidant activity of Nasturtium flowers (Tropaeolum majus). Food Chemistry, 114(1), 44-49. http://dx.doi.org/10.1016/j. foodchem.2008.09.013.

Gonçalves, R. F., Silva, A. M. S., Silva, A. M., Valentao, P., Ferreres, F., Gil-Izquierdo, A., Silva, J. B., Santos, D., \& Andrade, P. B. (2013). Influence of taro (Colocasia esculenta L. Shott) growth conditions on the phenolic composition and biological properties. Food Chemistry, 141(4), 3480-3485. http://dx.doi.org/10.1016/j.foodchem.2013.06.009. PMid:23993510.

González, C., Liste, A., \& Felpeto, A. (2011). Tratamiento de datos con $R$, Statistica y SPSS (1. ed.). Espanha: Diaz de Santos.

Hair, J., Black, W., Babin, B., Anderson, R., \& Tatham, R. (2009). Análise multivariada de dados (6. ed.). Porto Alegre: Bookman.

International Organization for Standardization - ISO. (2017). ISO 11136: sensory analysis: methodology: general guidance for conducting hedonic tests with consumers in a controlled. London: ISO.

Jabeur, I., Pereira, E., Barros, L., Calhelha, R. C., Soković, M., Oliveira, M. B. P. P., \& Ferreira, I. C. F. R. (2017). Hibiscus sabdariffa L. as a source of nutrients, bioactive compounds and colouring agents. Food Research International, 100(Pt 1), 717-723. http://dx.doi. org/10.1016/j.foodres.2017.07.073. PMid:28873741.

Jiménez-Aguilar, D. M., \& Grusak, M. A. (2017). Minerals, vitamin C, phenolics, flavonoids and antioxidant activity of Amaranthus leafy vegetables. Journal of Food Composition and Analysis, 58, 33-39. http://dx.doi.org/10.1016/j.jfca.2017.01.005.

Kinupp, V. F., \& Lorenzi, H. M. (2014). Plantas Alimentícias Não Convencionais (PANC) no Brasil: guia de identificação, aspectos nutricionais e receitas ilustradas. Nova Odessa: Odessa Instituto Plantarum.

Kumar, V., Sharma, H. K., \& Singh, K. (2017). Effect of precooking on drying kinetics of taro (Colocasia esculenta) slices and quality of its flours. Food Bioscience, 20(1), 178-186. http://dx.doi.org/10.1016/j. fbio.2017.10.003.

Lafraire, J., Rioux, C., Giboreau, A., \& Picard, D. (2016). Food rejections in children: cognitive and social/environmental factors involved in food neophobia and picky/fussy eating behavior. Appetite, 96, 347357. http://dx.doi.org/10.1016/j.appet.2015.09.008. PMid:26391004.

Latorres, J. M., Mitterer-Daltoé, M. L., \& Queiroz, M. I. (2016). Hedonic and word association techniques confirm a successful way of introducing fish into public school meals. Journal of Sensory Studies, 31(3), 206-212. http://dx.doi.org/10.1111/joss.12204.

Madeira, N. R., Amaro, G. B., Melo, R. A. C. E., Botrel, N., Rochinski, E. (2016). Cultivo de Ora-pro-nóbis (Pereskia) em plantio adensado sob manejo de colheitas sucessivas (Circular Técnica, No. 156). Brasília: Embrapa.

Martin, A. A., Freitas, R. A., Sassaki, G. L., Evangelista, P. H. L., \& Sierakowski, M. R. (2017). Chemical structure and physical-chemical properties of mucilage from the leaves of Pereskia aculeata. Food Hydrocolloids, 70, 20-28. http://dx.doi.org/10.1016/j.foodhyd.2017.03.020.

Menendez-Baceta, G., Pardo-de-Santayana, M., Aceituno-Mata, L., Tardío, J., \& Reyes-García, V. (2017). Trends in wild food plants uses in Gorbeialdea (Basque Country). Appetite, 112, 9-16. http:// dx.doi.org/10.1016/j.appet.2017.01.010. PMid:28087368.

Mitterer Daltoé, M. L., Breda, L. S., Belusso, A. C., Nogueira, B. A., Rodrigues, D. P., Fiszman, S., \& Varela, P. (2017). Projective mapping with food stickers: a good tool for better understanding perception of fish in children of different ages. Food Quality and Preference, 57, 87-96. http://dx.doi.org/10.1016/j.foodqual.2016.12.003.

Mlcek, J., \& Rop, O. (2011). Fresh edible flowers of ornamental plants: a new source of nutraceutical foods. Trends in Food Science \& Technology, 22(10), 561-569. http://dx.doi.org/10.1016/j.tifs.2011.04.006.

Morin-Audebrand, L., Mojet, J., Chabanet, C., Issanchou, S., Møller, P., Köster, E., \& Sulmont-Rossé, C. (2012). The role of novelty detection in food memory. Acta Psychologica, 139(1), 233-238. http://dx.doi. org/10.1016/j.actpsy.2011.10.003. PMid:22078108.

Mustonen, S., Hissa, I., Huotilainen, A., Miettinen, S. M., \& Tuorila, H. (2007). Hedonic responses as predictors of food choice: flexibility and self-prediction. Appetite, 49(1), 159-168. http://dx.doi.org/10.1016/j. appet.2007.01.005. PMid:17343956.

Oliveira, I., Valentão, P., Lopes, R., Andrade, P. B., Bento, A., \& Pereira, J. A. (2009). Phytochemical characterization and radical scavenging activity of Portulaca oleraceae L. leaves and stems. Microchemical Journal, 92(2), 129-134. http://dx.doi.org/10.1016/j.microc.2009.02.006.

Peter, K., \& Gandhi, P. (2017). Rediscovering the therapeutic potential of Amaranthus species: a review. Egyptian Journal of Basic and Applied Sciences, 4(3), 196-205. http://dx.doi.org/10.1016/j.ejbas.2017.05.001.

Pinto, N. D. C. C., Machado, D. C., Da Silva, J. M., Conegundes, J. L. M., Gualberto, A. C. M., Gameiro, J., Moreira Chedier, L., Castañon, M. C., \& Scio, E. (2015). Pereskia aculeata Miller leaves present in vivo topical anti-inflammatory activity in models of acute and chronic dermatitis. Journal of Ethnopharmacology, 173, 330-337. http:// dx.doi.org/10.1016/j.jep.2015.07.032. PMid:26226436. 
Riaz, G., \& Chopra, R. (2018). A review on phytochemistry and therapeutic uses of Hibiscus sabdariffa L. Biomedicine and Pharmacotherapy, 102, 575-586. http://dx.doi.org/10.1016/j.biopha.2018.03.023. PMid:29597091.

Rodrigues, A. P., Fontana, C. V., Padilha, E., \& Silvestrin, M. (2006). Elaboração de sorvete sabor chocolate com teor de gordura reduzido utilizando soro de leite em pó. Vetor, 16, 55-62.

Sanchez-Bel, P., Romojaro, A., Egea, I., \& Pretel, M. T. (2015). Wild edible plants as potential antioxidant or nutritional supplements for beverages minimally processed. Lebensmittel-Wissenschaft + Technologie, 62(1), 830-837. http://dx.doi.org/10.1016/j.lwt.2014.06.017.

Sarikurkcu, C., Kocak, M. S., Uren, M. C., Calapoglu, M., \& Sihoglu Tepe, A. (2016). Potential sources for the management global health problems and oxidative stress: Stachys byzantina and S. iberica subsp. iberica var. densipilosa. European Journal of Integrative Medicine, 8(5), 631-637. http://dx.doi.org/10.1016/j.eujim.2016.04.010.

Steptoe, A., Pollard, T. M., \& Wardle, J. (1995). Development of a measure of the motives underlying the selection of food: the food choice questionnaire. Appetite, 25(3), 267-284. http://dx.doi.org/10.1006/ appe.1995.0061. PMid:8746966.

Tuorila, H., Huotilainen, A., Lähteenmäki, L., Ollila, S., Tuomi-Nurmi, S., \& Urala, N. (2008). Comparison of affective rating scales and their relationship to variables reflecting food consumption. Food
Quality and Preference, 19(1), 51-61. http://dx.doi.org/10.1016/j. foodqual.2007.06.007.

Varela, P., \& Fiszman, S. M. (2013). Exploring consumers' knowledge and perceptions of hydrocolloids used as food additives and ingredients. Food Hydrocolloids, 30(1), 477-484. http://dx.doi.org/10.1016/j. foodhyd.2012.07.001.

Varela, P., Pintor, A., \& Fiszman, S. (2014). Food hydrocolloids how hydrocolloids affect the temporal oral perception of ice cream. Food Hydrocolloids, 36, 220-228. http://dx.doi.org/10.1016/j. foodhyd.2013.10.005.

Verbeke, W., \& Vackier, I. (2005). Individual determinants of fish consumption: application of the theory of planned behaviour. Appetite, 44(1), 67-82. http://dx.doi.org/10.1016/j.appet.2004.08.006. PMid:15604034.

Wang, J. M., Ji, L. L., Branford-White, C. J., Wang, Z. Y., Shen, K. K., Liu, H., \& Wang, Z. T. (2012). Antitumor activity of Dioscorea bulbifera L. rhizome in vivo. Fitoterapia, 83(2), 388-394. http:// dx.doi.org/10.1016/j.fitote.2011.12.001. PMid:22178682.

Xiang, L., Xing, D., Wang, W., Wang, R., Ding, Y., \& Du, L. (2005). Alkaloids from Portulaca oleracea L. Phytochemistry, 66(21), 2595-2601. http://dx.doi.org/10.1016/j.phytochem.2005.08.011. PMid:16203019. 